\title{
Evaluation of a Professional Social Skills Program for Unemployed People with Physical Disability
}

\author{
Avaliação de um Programa de Habilidades Sociais Profissionais \\ para Pessoas com Deficiência Física Desempregadas
}

\author{
Camila de Sousa Pereira-Guizzo ${ }^{*}, a$, Almir Del Prette ${ }^{b} \&$ Zilda Aparecida Pereira Del Prette ${ }^{b}$ \\ ${ }^{a}$ SENAI CIMATEC - Centro Integrado de Manufatura e Tecnologia, Salvador, Brasil \\ $\&{ }^{b}$ Universidade Federal de São Carlos, São Carlos, Brasil
}

\begin{abstract}
The literature on labor points out the importance of social skills for employability. This study analyses, on a multiple probe design with two separate groups, the efficiency and effectiveness of a Professional Social Skills Training Program designed for unemployed people with physical disabilities. The sample consisted of 16 people with physical disabilities, aged from 18 to 36, forming two intervention groups. They were assessed by quantitative and qualitative instruments. Results indicated gains in social skills after the intervention, maintenance of acquisitions in the follow-up and generalization of learned skills to the natural environment for both groups. Such results suggest benefits of the Program on the interpersonal and professional development of unemployed people with physical disability.

Keywords: social skills, professional education, physical disability, program evaluation, employment.
\end{abstract}

\begin{abstract}
Resumo
A literatura sobre trabalho aponta a importância das habilidades sociais para a empregabilidade. Este estudo avalia, sob delineamento de grupo com sondagens múltiplas, a eficácia e efetividade de um Programa de Desenvolvimento de Habilidades Sociais para o Trabalho junto a pessoas com deficiência física desempregadas. Participaram 16 pessoas, com idade entre 18 e 36 anos, que formaram dois grupos de intervenção e foram avaliados por meio de instrumentos quantitativos e qualitativos. Os resultados indicaram ganhos de habilidades sociais após a intervenção, manutenção das aquisições nas avaliações de seguimento e generalização das habilidades aprendidas para o ambiente natural em ambos os grupos. Tais resultados sugerem os benefícios do Programa para o desenvolvimento interpessoal e profissional de pessoas com deficiência física desempregadas.

Palavras-chave: Habilidades sociais, formação profissional, deficiência física, avaliação de programa, emprego.
\end{abstract}

The participation of Persons With Disabilities (PWD) in the formal labor market is a recent achievement, having been stimulated over the past years by inclusive legislation (Jaime \& Carmo, 2005). However, despite the efforts put forth through public policies and by Brazilian legislation in providing the support required to ensure these rights, the reality faced by the PWD have been characterized by

\footnotetext{
"This text is a modified part of the first author's Doctorate Thesis, in the Post-Graduation Program in Special Education of the Federal University of São Carlos, under the guidance of the second author, having counted on the cooperation of the third author in this analisis. Financial support: Fundação de Amparo à Pesquisa do Estado de São Paulo - Foundation for the Support of Research (FAPESP).

Address: Centro Integrado de Manufatura e Tecnologia, Faculdade de Tecnologia, Serviço Nacional de Aprendizagem Industrial, Av. Orlando Gomes, 1845, Piatã, Salvador, BA, Brasil 41650-010. E-mail: camila.pereira@fieb.org.br, adprette@ufscar.bre zdprette@ufscar.br
}

the lack of opportunities in society. Law $\mathrm{n}^{\circ} 8.213$, for example, passed on the 24th of July, 1991, better known as the Quota Law, determines that companies with 100 or more employees must set apart 2 to $5 \%$ of their staff positions for individuals with disabilities who are qualified or rehabilitated for the job. However, many studies show that the majority of these companies have not been filling the quotas (Fernandes \& Rolli, 2008; Gomes, 2005; Jaime \& Carmo, 2005).

The companies' justifications for their nonclompliance are diverse. In a study conducted by Tanaka and Manzini (2005) with individuals responsible for the human resources departments of companies in the fields of trade, industry and services, the following were identified as being the main constraints in admitting PWD: (a) the candidates lack of experience in dealing with groups and in performing certain tasks, (b) the low level of education common to this group, (c) the absence of interpersonal development programs aimed at preparing professionals 
to deal with the current demands of their labor market. Tanaka and Manzini (2005) and other investigators (Câmara, Sarriera, \& Pizzinato, 2004; Cournoyer, 2007; Donohue et al., 2005) indicate that, in addition to technical expertise and to the level of education, employers currently value an individual's competence in making and maintaining relationships with different people in the work environment (superiors, colegues, clients etc).

As a matter of fact, while analyzing the interrelationships of the employability model, proposed by Câmara et al. (2004), the appreciation of peculiar aspects, such as social skills for the job, stand out from the young professional's profile at a mesosystemic level. The concept of professional social skills is defined by A. Del Prette and Del Prette (2001, p. 89) as, "those that attend to the different interpersonal demands of the work environment, aiming at the achievement of goals, the preservation of the group's well-being and the respect for each individuals rights". Coherently, literature has emphasized the importance of improving the repertoire of professional social skills for workers with physical disabilities as one of the conditions for employment (Pereira \& A. Del Prette, 2008).

A physical disability can be understood as a disturbance in the anatomic structure or in the function of the human body, resulting in the impairment of motor skills or mobility (Hallahan \& Kauffman, 2003). Anatomic and physiological alterations may occur due to lesions in the skeletal, articular, muscular, circulatory or nervous systems. The aetiologies are many, but usually involve genetic factors, diseases, problems during pregnancy or childbirth. Physical disabilities entail a variety of stressors which are characteristic of this condition, such as physical restraints while performing certain activities and issues related to other people's intolerance, along with the psychological demands associated to the diagnosis, which may influence the way the individual copes with the disability and even his or her social and professional adjustment (Perry, Hendricks, \& Broadbent, 2000; Wilson, Washington, Engel, Ciol, \& Jensen, 2006). Even though environmental variables are important while coping with physical disabilities, the individual's repertoire of social skills can favor resilience and protective mechanisms in the face of the stressful factors to which they are exposed to, as well as to facilitate the PWD's exposure to various interpersonal situations, increasing his or her likelihood of obtaining external reinforcers such as social support, friendships and achievement opportunities (Z. A. P. Del Prette \& Del Prette, 2005; Murta \& Guimarães, 2007).

Given the importance of the behavioral repertoire to the professional insertion and development, Pereira, A. Del Prette and Del Prette (2009) analyzed the social skills of workers with physical disabilities (WPD) in comparison to workers without physical disabilities (WND). The results showed more similarities than differences between the groups in regard to their social skills. However, the differences were not in favor of WPD. Other studies
(Pereira \& A. Del Prette, 2008; Thomas, Bax, \& Smyth, 1988) indicated that these individuals presented difficulty or low frequency in some classes of social skills that are important in a professional context, such as introducing oneself to another person, speaking in public, making friends, dealing with criticisms and teasing and offering help. Z. A. P. Del Prette and Del Prette (2005, p. 27) also report that "motor impairment may hinder the issuing and regulation of behavioral components which are characteristic of socially competent performance". Social skill deficits may interfere with the social performance during a job interview and throughout the practice of a profession, thereby impairing the attainment of success in such situations.

Social Skills Programs, aimed at overcoming the different kinds of social skills deficits, as well as maximizing the repertoire of social behaviors, can be formally conducted and represent a potentially effective alternative. However, it is known that social skills programs are not usually included as part of the formal curriculum of most of the educational and vocational institutions for people with or without disabilities (Z. A. P. Del Prette \& Del Prette, 2003). In addition, there has been very little research on social skills in the work environment focusing specifically on PWD (Bolsoni-Silva et al., 2006). Such a gap was also highlighted by Mendes, Nunes, Ferreira and Silveira (2004) in a revision of thesis and dissertations produced by Special Education and Psychology graduate programs. They identified 479 dissertations and theses, but only $18(3.5 \%)$ focused on the theme of the professionalization of the PWD.

The present study had as an objective the evaluation of a Program for the Development of Labor Social Skills designed for unemployed persons with disabilities. More specifically, it aimed at evaluating the efficiency (acquisition and improvement of the social skills that were targeted by the program) and effectiveness (maintenance, generalization and impact of these acquisitions). The intervention program was applied to two groups under a multiple probe design.

\section{Method}

This study complied with Resolution 196/96 of the National Board of Health regarding the Guidelines and Regulatory Norms for Research Involving Human Beings. It was approved by the Ethics Committee of the Federal University of São Carlos (Ruling n 095/2006).

\section{Participants}

The two groups added up to 16 participants, eight belonging to each. They were aged 18 to 36 years old and were selected based on the following criteria: (a) having a physical disability; (b) not working, but seeking to be inserted into the labor market; and (c) consenting to participate in the research. Table 1 presents the main characteristics of the groups. 
Pereira-Guizzo, C. S., Del Prette, A. \& Del Prette, Z. A. P. (2012). Evaluation of a Professional Social Skills Program for Unemployed People with Physical Disability.

Table 1

Characteristics of the Sample, According to the Composition of Groups $G 1(n=8)$ and $G 2(n=8)$

\begin{tabular}{llcc}
\hline Variables & Levels & $\mathrm{G} 1$ & $\mathrm{G} 2$ \\
\hline Gender & Female & 5 & 6 \\
& Male & 3 & 2 \\
Age & 18 to 27 years & 3 & 5 \\
& 28 to 36 years & 5 & 3 \\
Schooling & Average $(D P)$ & $29(5.8)$ & $24.9(5.6)$ \\
& Incomplete Elementary & 1 & - \\
& Complete Elementary & - & - \\
& Incomplete Highschool & 1 & 6 \\
Economic Class & Complete Highschool & 6 & 1 \\
Physical Disability & Incomplete College & - & $15.5(3.1)$ \\
& Average $(D P)$ & $13.1(4)$ & 4
\end{tabular}

Both groups had half of their composition accounted for by participants with innate disabilities; the other half was made up of participants who had acquired their disabilities, both requiring the use of resources such as the following: walker $(\mathrm{G} 1=1)$; wheel chair $(\mathrm{G} 2=2)$; crutches (one participant from each group); bracing (ditto); and prosthesis (G2=1). There were no significant age differences between the two groups $(t=1.451 ; p=$ .169). The groups were also comparable in regards to their socioeconomic levels, according to the Critério Brasil-Brazilian Criteria ${ }^{1}(t=-1.322 ; p=.208)$ : they were distributed throughout classes $\mathrm{B}$ to $\mathrm{D}(\mathrm{G} 1: \mathrm{B} 2=2, \mathrm{C}=4$ e $\mathrm{D}=2 ; \mathrm{G} 2: \mathrm{B} 1=1$ and $\mathrm{C}=7$ ). Most of the participants of each group were females with complete high school educations. Among the causes or consequences of the physical disabilities, the following were identified: head injury with long lasting effects to the upper and lower parts of the body (hemiparesis); cerebral paralysis, affecting both motor coordination and locomotion; idiopathic and hereditary neuropathy with motor sequelae; traumatic amputation of fingers; amputation of both legs; diffuse cerebral injury with the fractures of the femur, leg, shoulder and arm; scoliosis and osteoporosis; shortness of the leg; hemiparesis; muscular dystrophy; spinal cord injury (paraplegia). In G1, all of the participants had already had professional experience. In G2, six participants had previously worked.

The participants went through an initial evaluation in order to analyze the necessity of the intervention. This

\footnotetext{
${ }^{1}$ The Brazilian Economic Classification Criteria Critério de Classificação Econômica Brasil by Association of Brazilian Research Companies, 2003, (http:/ /www.abep.org) is a public domain instrument which measures the consumer's purchasing power and has been used to classify the Brazilian population in economic terms. The population is divided in seven classes of purchasing power: A1, A2, B1, B2, C, D e E.
}

evaluation pointed out the main difficulties the subjects experienced during recruitment processes, the feelings they experienced as well as their expectations concerning their future as professionals. A Social Skills Inventory, completed by the participants, showed that most of the participants had deficient social skills repertoires. Through interviews, indicators of depression were reported by two of the participants.

\section{Location for Data Colection}

The study was conducted in two institutions that supported persons with physical disabilities, but that did not carry out training programs aimed at inserting them into the labor market. The participants of G1were from Institution A, which is bound to the Municipal Bureau of Social Welfare of a city located out in the country of the state of São Paulo with approximately 500 thousand inhabitants; G2 was from Institution B, a philanthropic association located in another city nearby, with approximately 50 thousand inhabitants.

\section{Instruments}

Social Skills Inventory - SSI-Del-Prette (Z. A. P. Del Prette \& Del Prette, 2001). It is a self-report instrument, designed for the evaluation of the social skills repertoire of teenagers and adults, recommended by the Federal Board of Psychology for its psychometric qualities. It presents 38 items which describe interpersonal situations in various different contexts, presenting varied demands for social skills. The participant is asked to estimate the possible frequency with which he or she performs the social skill described in each item, considering the total amount of times in which he or she faced that situation, indicating his or her answer on a five point Likert scale (from $0=$ never or rarely to $4=$ always or almost always). The SSI-Del Prette delivers a total score and scores for five factors: Confrontation and self-assertion with risk; 
Self-assertion through the expression of positive feelings; Conversation and social nimbleness; Self exposure to the unknown and to new situations; and Self-control over aggressiveness.

Professional Social Skills Observation System - PSSOS. This is a version of A. Del Prette's and Pereira's (2008) instrument, adapted for people with physical disabilities. It is composed of three video recorded structured situations (SS), analized in accordance with the guidance of the Record of the Observations of Professional Social Skills (ROPSS). The structured situations present demands for the following professional social skills: (a) Facing $a$ job interview: greet, present oneself to another person, answer questions, carry out self promotion, ask questions and bid farewell; (b) Offering a colleague some help: commence conversation, expressing comprehension and opinions; and (c) Dealing with a superior's fair criticism: apologize, admit mistakes, express the intention to change behavior and express agreement. In order to conduct these situations, a previously trained assistant was included in order to perform role-playing among the participants who were being studied. The ROPSS is composed of scripts for the performances of professional social skills in structured situations, captured through video recordings in order to identify verbal, nonverbal and paralinguistic components as well as the quality of the performance on a five point Likert scale, $(0=A b s e n t ; 1=B a d ; 2=N o t$ good or bad; $3=$ Good ; 4 =Very Good). The internal consistency of the items in all three situations produced a Cronbach's Alfa of .67.

Record of video footages. Logbook of items portraying indications of progress and generalization, related to the participation in the program and observed during the filming of the intervention sessions.

Field Logbook. Pad of paper for registering casual and spontaneous statements, indicating progress and generalization.

\section{Data collection}

The intervention occurred separately with each group (G1 and G2). In accordance with the multiple probe design (Horner \& Baer, 1978), each one of them was evaluated four times as depicted on Table 2.

Table 2

Delineation Stages of the Multiple Probe Design with Both of the Groups Involved in this Research

\begin{tabular}{lcccccc}
\hline Group & Evaluation 1 & Program & Evaluation 2 & Program & Evaluation 3 & Evaluation 4 \\
\hline G1 & $\mathrm{X}$ & $\mathrm{X}$ & $\mathrm{X}$ & - & $\mathrm{X}$ & $\mathrm{X}$ \\
G2 & $\mathrm{X}$ & - & $\mathrm{X}$ & $\mathrm{X}$ & $\mathrm{X}$ & $\mathrm{X}$ \\
\hline
\end{tabular}

In both groups, there was a two month interval between the evaluations of the dependent variables. As can be seen, the difference between the groups was that with G1 the intervention occurred right after the first evaluation, while with G2, the intervention occurred later on, after a second evaluation. The groups went through at least two evaluations following the intervention, one of them was immediately after the conclusion and the other, two months later, based on the SSI-Del-Prette and on the video recordings of performance in structured situations (Professional Social Skills Observation System).

The SSI-Del-Prette evaluations were conducted by the researcher in group settings, taking up approximately 30 minutes so that the participants could read the instructions and fill out the answer sheets. The structured situations concerning the performance of roles were conducted individually, with approximately 10 minutes per person, which were video recorded. The recordings of the sessions were transcribed onto the logbook. The entries in the field logbook were carried out in handwriting, while in contact with the participants.

\section{The Intervention}

The Program for the Development of Social Skills for the Work Environment was composed of 16 group sessions, carried out twice a week, lasting approximately
90 minutes each, and were conducted by the researcher (first author). Grounding itself upon the theoretical and practical fields concerning Social Skills, the Program aimed at the acquisition and improvement of the social skills that are relevant in a job interview and for overall interpersonal and professional achievement.

The sessions were organized in a sequence of increasing complexity of the social skills that were targeted by the Program which include the following: civility, feedback, communication, empathy, offering help, citizenship, assertiveness, dealing with criticism, problem solving, performance in a job interview and expressing positive feelings. The skills were defined based on the participants' needs (initial evaluation), as well as on their relevance as pointed out through literature. The themes and procedures were previously tested through an initial study. The physical limitations of each participant were considered in the educational procedures in order to guarantee that all had access to the program's activities.

The overall structure of the Program was based on the experiential method (A. Del Prette \& Del Prette, 2001; Z. A. P. Del Prette \& Del Prette, 2005) associated with cognitive-behavioral techniques such as behavior rehearsal, positive reinforcement, modeling, verbal feedback, video feedback and homework. Educational activities were also used, such as making posters, drama, film analyses and 
storybook reading. Each session was organized in three parts: (a) initial - when participants give a report of their homework assignment, receiving the group's support, and a brief summary of the previous session is made before initiating the new session; (b) central - with the application of the procedures which had been previously planned; (c) final - with the assignment of homework and a request for feedback concerning the session.

\section{Data Processing}

The data was organized in the Statistical Package for Social Sciences (SPSS for Windows 16.0). Taking the sample size and the asymmetric distribution of the results into account, the results were analyzed using descriptive statistics (based on the median) and nonparametric statistics (Mann-Whitney to determine the differences between the groups in each evaluation and Friedman in order to analyze the gains made by each group overtime).
A significance level of less than or equal to .05 was adopted. The reliability of the assessment of the footages carried out through the PSSOS was tested in $52 \%$ of the situations $(N=96)$ resulting in the judges' approval of the researcher's evaluation, over $95 \%$.

\section{Results}

The results are presented below, starting with the selfreports (SSI-Del-Prette) followed by the performance in the structured situations (PSSOS). Lastly, the Evaluation form for videotaped performances and the Field Logbook indicate generalizations.

\section{Social Skills Inventory (SSI-Del-Prette)}

Figure 1 illustrates the median of the Total Score and of the SSI-Del-Prette factors, throughout all of the four evaluations to which each group was submitted.
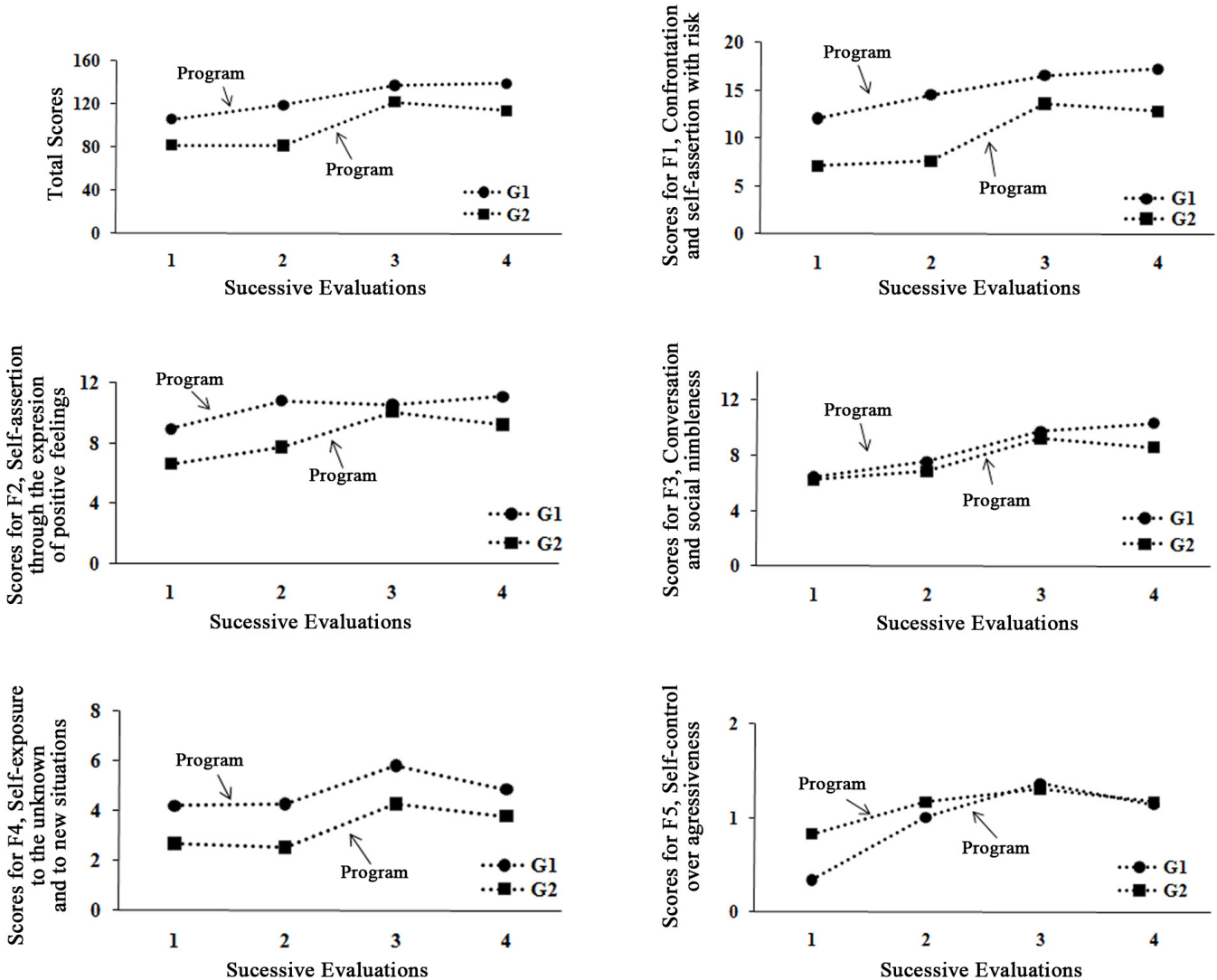

Figure 1. Median of G1's and G2's total score subscales in the SSI-Del-Prette for all four of the evaluations which were conducted.

In the Total Score (TS) of the SSI-Del-Prette, the groups did not present statistically significant differences in the initial evaluation ( $U=14.0 ; z=-1.9 ; p=.058)$. However, as early as the second assessment (after the intervention), significant improvements were already observed in G1 $(U=.10 ; z=-3.4 ; p=.001)$ which increased in the third evaluation - first follow-up assessment $(U=8.5 ; z=-2.5$; $p=.014)$, and was maintained in the second follow-up assessment (Evaluation 4: $U=3.5 ; z=-2.7 ; p=.008$ ). G2 maintained its initial scores throughout both of the preintervention evaluations, improving and then maintaining higher scores after the intervention $\left(\chi^{2}=20.700 ; p<.001\right)$. 
The groups were, however, benefited by the Program even though G1 had consistently presented better results in all evaluations.

As for Factor 1 (Confrontation and self-assertion with risk) a tendency, similar to the one present in the total score, was observed, even though the initial evaluation (Evaluation 1) had shown a difference between the groups in favor of G1 $(U=7.0 ; z=-2.6 ; p=.009)$. Despite the initial differences, G1 continued improving the skills related to this factor, both in the post-intervention assessment (Evaluation $2: U=1.0 ; z=-3.3 ; p=.001)$ and in the follow-up assessments (Evaluation 3: $U=9.0 ; z=-2.4 ; p=.016$; Evaluation $4: U=2.0 ; z=-2.8 ; p=.005)$. G2 virtually maintained the initial scores throughout both of the pre-intervention assessments, increasing and then maintaining higher scores after the intervention $\left(\chi^{2}=19.950 ; p<.001\right)$. Therefore, it was possible to conclude that the Program benefited both groups in the skills comprised by Factor 1 .

Concerning Factor 2 (Self-assertion through the expression of positive feelings), the results also display the impact of the Program and the preservation of the results. Both groups were statistically similar in the initial evaluation ( $U=16.0 ; z=-1.7 ; p=.093$ ), however, significant improvements had been achieved by G1 in comparison to $\mathrm{G} 2$, immediately after the intervention $(U=3.0 ; z=-3.1$; $p=.002)$. No development or differences were observed between the groups in G1's follow-up assessments (Evaluation 3: $U=25.0 ; z=-.7 ; p=.462$; Evaluation 4: $U=11.0 ; z=-1.7 ; p=.093)$, since it was only after the intervention that improvements were to be identified in G2 in regards to this factor, which practically remained stable during the follow-up $\left(\chi^{2}=17.354 ; p=.001\right)$.

In Factor 3 (Conversation and social nimbleness), G2's gains were clearly subsequent to the intervention and with the preservation of the improvements in the follow-ups $\left(\chi^{2}=12.797 ; p=.005\right)$; however G1's gains occurred more gradually, with an increase in the follow-up (Evaluation 3 ) and preservation in the final evaluation $\left(\chi^{2}=12.000\right.$; $p=.007)$. In accordance with a self-report, the groups did not present significant statistical differences in the initial evaluation $(U=30.0 ; z=-.2 ; p=.834)$, nor in Evaluation 2 $(U=19.0 ; z=-1.4 ; p=.172)$ and Evaluation $3(U=27.0 ; z=$ $-.5 ; p=.599)$, being that there was only a significant difference in the last follow-up evaluation, Evaluation $4(U=5.0$; $z=-2.5 ; p=.014$ ), which was more favorable to G1.

As for Factor 4 (Self exposure to the unknown and to new situations), apparently the Program did produce changes in G1, even though changes were observed in the first follow-up assessment (Evaluation 3: $U=.1 ; z=-$ $3.5 ; p=.001)$ and deteriorated partially in the last one. In G2, the data was more consistent, with the improvement after the intervention and the maintenance of these gains throughout the course of time $\left(\chi^{2}=17.550 ; p=.001\right)$.

In Factor 5 (Self-control over aggressiveness), the groups reported differences only in the pre-intervention evaluation ( $U=13.0 ; z=-2 ; p=.046$ ), favoring G1. After the intervention, G1 presented improvements in relation to previous assessments $\left(\chi^{2}=10.620 ; p=.014\right)$, but did not differ significantly from G2. In G2, significant improvements were not observed, even though the initial differences between the groups no longer took place.

\section{Professional Social Skills Observation System (PSSOS)}

The topographical quality of the social performance in three situations was evaluated using the PSSOS. Figure 2 shows the scores that were obtained in the different situations, considering the minimum score to be 0 and the maximum to be 24 (for Facing a job interview), 12 (for Offering a colleague some help) and 16 (for Dealing with a superior's fair criticism).
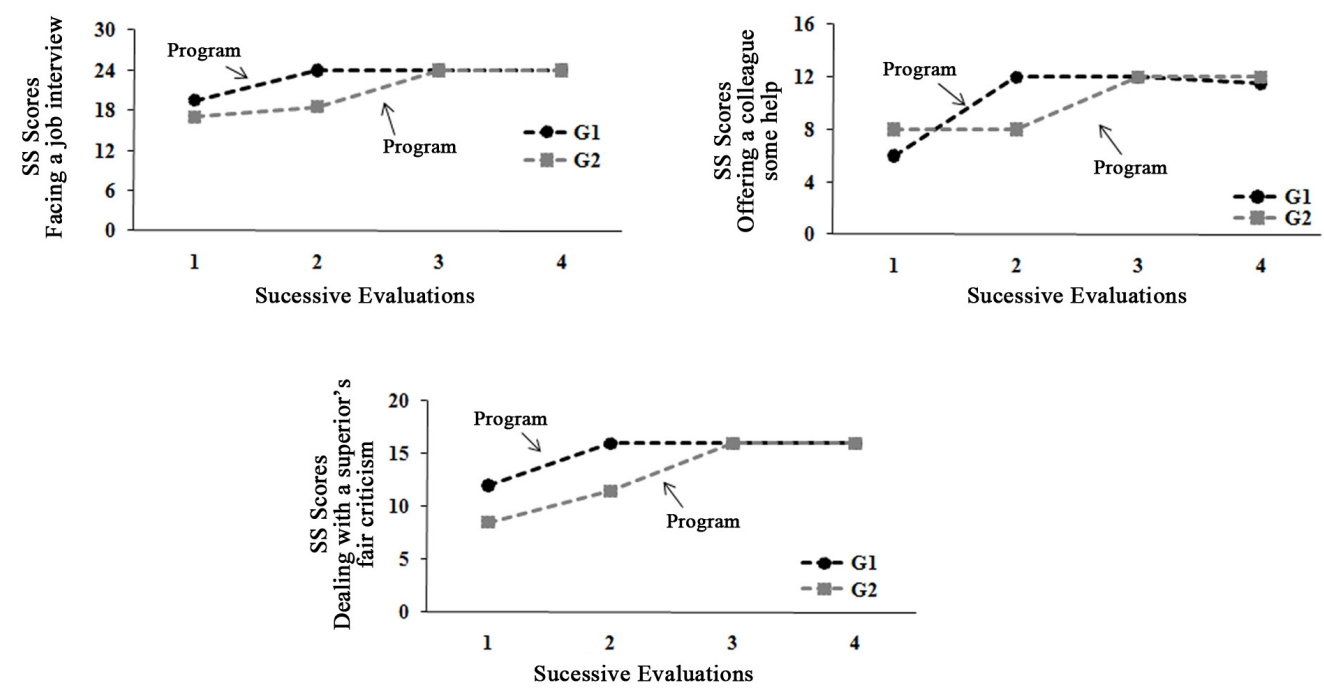

Figure 2. Median of the scores that were achieved by the participants of G1 and G2 in the Structured Situations (SS) of: Facing a job interview, Offering a colleague some help and Dealing with a superior's fair criticism. 
Pereira-Guizzo, C. S., Del Prette, A. \& Del Prette, Z. A. P. (2012). Evaluation of a Professional Social Skills Program for Unemployed People with Physical Disability.

In what concerns Facing a job interview, the groups did not present differences in the initial evaluation (Evaluation 1: $U=18.5 ; z=-1.4 ; p=.155)$. However the impact of the Program was observed in the evaluation following the intervention (Evaluation 2: $U=2.0 ; z=-3.3 ; p=.001$ ). Likewise, the impact the Program had over G2 was observed during the different evaluations $\left(\chi^{2}=22.833 ; p<\right.$ $.001)$. The maintenance of gains was clearly made evident in both groups' follow-ups. Therefore, the groups were benefited by the Program, reaching the top score available for the record of observation.

The comparative analyses concerning the performance in Offering a colleague some help did not present any differences between the groups in the pre-intervention evaluation (Evaluation 1: $U=21.5 ; z=-1.1 ; p=.258$ ). However, in the post-intervention evaluation (Evaluation 2), G1's score increased significantly ( $U=13.0 ; z=-2.1$; $p=.032)$. The acquirements that resulted from the participation in the Program were also observed in G2 $\left(\chi^{2}=14.529 ; p=.002\right)$. In the follow-up assessment, both groups also maintained the improvements that were obtained through the Program.

In the situation designated as Dealing with a superior's fair criticism, the groups did not present differences in

Table 3

Some of the Reports Concerning Progress and Generalization of the Participants the pre-intervention evaluation (Evaluation 1: $U=22.5$; $z=-1.0 ; p=.312$ ). The positive impact that the Program had was noted due to G1's improvements in the postintervention assessment (Evaluation 2: $U=12.0 ; z=-2.2$; $p=.030)$. G2 was also benefited by the Program, as can be observed through the different evaluations $\left(\chi^{2}=20.829\right.$; $p<.001)$. Beyond the improvements obtained after the intervention, it was possible to observe that both groups continued learning in the follow-up evaluations.

\section{Evaluation Form for Videotaped Performances and Field Logbook}

Table 3 contains some excerpts from the accounts which can be taken as indicators of the generalization of the skills which were trained during the sessions. Such accounts, which were extracted from the Evaluation form for videotaped performances (EFVP) and from the Field Logbook (FL) occurred primarily during the review of the homework at the beginning of each session and during other situations, such as the snack at the end of the session, almost always occurring through the initiative of the participants themselves. The participants spontaneously continued to report progress and generalization, during the the follow-up evaluations and during the interactions which took place after such evaluations.

Record of video footages

When you see yourself in a situation . . . we begin to remember, to look back over the Program. Now I observe more (Aline, G1).

I learned things that I did not use to apply to my life: visual contact, being assertive for your rights (Fabiana, G1).

... In the bus a gentleman looked at the backpack which was on a seat and then to the young man. The gentleman said 'Excuse me, I don't think the backpack needs to rest!' I realized that the gentleman was being assertive (Aline, G1).
With the Program's help ... I now know how to deal with a situation: talk, think before acting (Paulo, G2).

The things from the Program are already with me on a day-today basis. . . I am more alert, I pay more attention (Ivete, G2).

My sister in law noticed that I have changed. . . . Before I had tense features, I have even changed in the way I interact with my daughter and with my husband. I use what I learn in the program over at home (Olinda, G2).

Field Logbook

Aline (G1) said that she is more communicative, interested in knowing about her health. She talked about how she was happy for having succeeded in going through a company's selection process.

Gerusa (G1) reported that the Program was helping her, she was more motivated, happy, she was able to get a well paying job, allowing her to be financially independent.

Henrique (G1), Eduardo (G1) and Carolina (G1) said that after having participated in the Program they were able to get jobs.
Paulo's Mother (G2) said that he improved his relationship with the family a lot after taking part in the Program.

Ivete $(\mathrm{G} 2)$ reported that she was approved in a job interview, gaining a place in the company. She said that the Program really helped her to achieve this goal.

Janaína (G2) reported that she was able to get a job. She was very happy! It is her first formal job after the accident she suffered.

Note. The names are fictitious. 
As shown on Table 3, these reports suggest that the participants began observing, differentiating and "choosing" different alternatives for performances during day-to-day situations (family, friends, strangers and job interviews). They also allow one to infer that others approved the acquirements and that the participants began using new terms, with the correct corresponding meanings (for example, assertiveness and civility).

The reports given by the participants of G1 and G2 suggest diverse benefits which the Program provided them with, to both their personal and professional lives, such as obtaining employment, consequently gaining greater autonomy. There were also reports which indicate an improvement in self-esteem and greater self-control over interpersonal situations.

\section{Discussion}

In regards to the SSI-Del-Prette, the results show the Program's immediate impact over both groups. Because of the study design adopted, the results for G1 were, in a certain way, replicated with $\mathrm{G} 2$, which seems to confirm the internal validity of the procedure (Cozby, 2003; A. Del Prette \& Del Prette, 2011; Kazdin, 1982).

The follow-up assessments show that a large part of the skills learned by both groups were maintained, suggesting the Program's effectiveness. This result was also found in other intervention researches (A. Del Prette \& Del Prette, 2011), revealing the impact of the Skill Training Programs for different problems.

The data resulting from the direct observation of the participant's performances in structured situations richly confirmed the Program's benefits. In all three of the structured situations (Facing a job interview, Offering $a$ colleague some help and Dealing with a superior's fair criticism) the identification of important gains were identified in both groups' participants, as well as maintaining this spirit of leaning throughout the last evaluations. The acquirement of skills for job interviews and other professional experiences are in accordance with the findings of A. Del Prette and Del Prette (2003), Donohue et al. (2005) and Sarriera, Câmara and Berlim (2000), which also proved the importance of developing social skills in preparation for the labor environment.

Another key point in the evaluation of a program is to verify if its effects occur in other environments that go beyond the training context, conferring the external validity (Cozby, 2003; Z. A. P. Del Prette \& Del Prette, 2005; Gresham, 2009). The participants reported the use of the social skills while facing job interviews in a natural environment, suggesting still the desensitization before such situations and the most positive assessment of their competence while obtaining success in the results of the selection. The fact that this learning experience was maintained and generalized could be due to planning and due to the possibility that the natural environment itself provided reinforcing consequences in the face of such acquirements, as some studies debate (Z. A. P. Del Prette \& Del Prette, 2005; Gresham, 2009). These results show that the training of social skills for the work environment is able to provide advantages in referring individuals to recruitment agencies, exceeding in performance in the face of job interviews and having confidence to seek employment, which is also supported by the findings from other studies (A. Del Prette \& Del Prette, 2003; Donohue et al., 2005; Sarriera et al., 2000).

Thus, the results of this study indicated that the Program produced positive effects over the frequency with which social skills were used and over the quality of the social performance in job interviews and professional situations. The improvements were maintained for at least a period of two to four months, in the majority of the measured variables. Furthermore, taking into account the design which was adopted, these results were essentially replicated in the second intervention group, suggesting the internal and external validities of this program as well as the overall solidness of the Social Skills Program, in accordance to previous studies.

The findings of this study carry some implications to be considered. Primarily, they suggest the importance of including social skills for the work environment in the curriculum of educational institutions as well as in professionalizing services, as is also suggested in other studies (Câmara et al., 2004; Cournoyer, 2007; Z. A. P. Del Prette \& Del Prette, 2003; Tanaka \& Manzini, 2005). By inserting this Program into educational phases, ranging from Elementary and High School to Professionalizing and College Education in particular, the chances of including a greater number of PWD into the regular networks are increased, having the same positive effects over the people with no physical disabilities.

In this sense, some important ingredients for the Program for the Development of Social Skills for the Work Environment can be drawn up: (a) the group setting with procedures that allow experiences to be the exchanged, to create bonds of friendship and to establish social support; (b) use of the experiential method (A. Del Prette \& Del Prette, 2001) as an educational approach for teaching social skills, where cognitive and behavioral techniques can be used in a complementary manner; (c) planning the teaching of process skills (how to observe and describe behaviors, to give positive feedback and to praise others) in order to favor the learning of the more complex social skills and solidifying the group as a therapeutic agent; (d) programming generalization through the use of homework and through the promotion of social skills which are significant of the natural environment and for the participant's complaints.

\section{Concluding Remarks}

Consistent with the finding of this research, the development of professional social skills contributes to the preparation of the individual for labor, giving him or 
Pereira-Guizzo, C. S., Del Prette, A. \& Del Prette, Z. A. P. (2012). Evaluation of a Professional Social Skills Program for Unemployed People with Physical Disability.

her better employability conditions and, with that, employability and professional progression. First of all, this adheres to the employers' requirements of the employee's capacity of relating with other people in the workplace obtaining, consequently, success in staff selection processes; on the other hand, this promotes behavioral resources for satisfactorily handling diverse demands made by the interpersonal and professional situations which, in turn, favor the adjustment and the "survival" in the workplace. This amplifies the Program's power, valuing its application in different services and in the various associations specialized in PWD. However, it is worth highlighting that such an initiative does not substitute the responsibility the companies have in considering the diversity of people; it is also important that they do their part in promoting favorable conditions for the professional development of persons with disabilities.

Another aspect that deserves attention is the planning of an intervention which takes into account the specificities of each disability. In addition to the selection of activities that adhere to the physical needs of the target population, it was essential to have a place for the intervention which was free of architectural barriers. Offering adapted means of transportation is also of extreme importance for the participation and accessibility of people with disabilities in society. Such care has contributed to the adhesion of the participants to this Program.

Some of the limitations presented by the methodological features adopted in this study (multiple probe design, sample selection, program planning, multimodal evaluation, data processing) must be recognized. One of them refers to re-testing and to the possible interaction between the dependent variable and the independent variable (intervention). One cannot disregard the hypothesis which holds that the SSI-Del-Prette evaluation and the structured situations, in four different moments, could have affected the scores of the repeated applications. In G2, there were two pre-intervention applications in a two month waiting interval. Even though both of G2's initial applications do not seem to impact the evaluation results, these effects could be better tested in future studies. Still, these procedures could have generated the participant's expectations and made them sensitive to what the objectives of the Program were. In order to control such variables, a third group could have been used only for repeated evaluations, without an intervention.

Some limitations must also be pointed out in what regards external validity. The composition of a small sample limits the generalizability of the results, which is partially lessened because of the fact that the groups were from different cities. The application of the program with an expanded sample and in various different regions of the country could guarantee a greater generalizability the results.

\section{References}

Bolsoni-Silva, A. T., Del Prette, Z. A. P., Del Prette, G., Montanher, A. R. P., Bandeira, M., \& Del Prette, A. (2006). A área das habilidades sociais no Brasil: Uma análise dos estudos publicados em periódicos. In M. Bandeira, Z. A. P. Del Prette, \& A. Del Prette (Eds.), Estudos sobre habilidades sociais e relacionamento interpessoal (pp. 17-45). São Paulo, SP: Casa do Psicólogo.

Câmara, S. G., Sarriera, J. C., \& Pizzinato, A. (2004). Que portas se abrem no mercado de trabalho para os jovens em tempo de mudanças? In J. C. Sarriera, K. B. Rocha, \& A Pizzinato (Eds.), Desafios do mundo do trabalho: Orientação, inserção e mudanças (pp. 73-113). Porto Alegre, RS: Editora da Pontifícia Universidade Católica do Rio Grande do Sul

Cournoyer, B. R. (2007). The social work skills workbook. Belmont, CA: Thomson Brokks/Cole.

Cozby, P. C. (2003). Métodos de pesquisa em ciências do comportamento. São Paulo, SP: Atlas.

Del Prette, A., \& Del Prette, Z. A. P. (2001). Psicologia das relações interpessoais: Vivencias para o trabalho em grupo. Petrópolis, RJ: Vozes.

Del Prette, A., \& Del Prette, Z. A. P. (2003). No contexto da travessia para o ambiente de trabalho: Treinamento de habilidades sociais com universitários. Estudos de Psicologia (Natal), 8, 413-420.

Del Prette, A., \& Del Prette, Z. A. P. (Eds.). (2011). Habilidades sociais: Intervenções efetivas em grupo. São Paulo, SP: Casa do Psicólogo.

Del Prette, A., \& Pereira, C. S. (2008). Procedimentos de observação em situações estruturadas para avaliação de habilidades sociais profissionais de adolescentes. Revista Psicolog, 1, 55-67.

Del Prette, Z. A. P., \& Del Prette, A. (2001). Inventário de Habilidades Sociais (IHS-Del-Prette): Manual de aplicação, apuração e interpretação. São Paulo, SP: Casa do Psicólogo.

Del Prette, Z. A. P., \& Del Prette, A. (2003). Desenvolvimento interpessoal: Uma questão pendente no ensino universitário. In E. Mercuri, \& S. A. J. Polydoro (Eds.), Estudante universitário: Características e experiências de formação (pp. 105128). Taubaté, SP: Cabral.

Del Prette, Z. A. P., \& Del Prette, A. (2005). Psicologia das habilidades sociais na infância: Teoria e prática. Petrópolis, RJ: Vozes.

Donohue, B., Conway, D., Beisecker, M., Murphy, H., Farley, A., Waite, M., \& et al. (2005). Financial management and job social skills training components in a summer business institute: A controlled evaluation in high achieving predominantly ethnic minority youth. Behavior Modification, 29, 653-676

Fernandes, F., \& Rolli, C. (2008, 3 ago.). Empresas descumprem cota para deficiente. Folha de São Paulo, pp. B8.

Gomes, F. F. (2005, 24 jul.). Maioria não cumpre cota para deficiente. Folha de São Paulo, pp. G1.

Gresham, F. M., (2009). Análise do comportamento aplicada às habilidades sociais. In Z. A. P. Del Prette \& A. Del Prette (Eds.), Psicologia das habilidades sociais: Diversidade teórica e suas implicações (pp. 17-66). Petrópolis, RJ: Vozes.

Hallahan, D. P., \& Kauffman, J. M. (2003). Exceptional leaners: Introduction to Special Education (pp. 431-451). New York: Allyn and Bacon.

Horner, R. D., \& Baer, D. M. (1978). Multiple-probe technique: A variation of the multiple baseline. Journal of Applied Behavior Analysis, 11, 189-196. 
Jaime, L. R., \& Carmo, J. C. (2005). A inserção da pessoa com deficiencia no mundo do trabalho: $O$ resgate de um direito de cidadania. São Paulo, SP: Ed. dos Autores.

Kazdin, A. E. (1982). Single-case research designs: Methods for clinical and applied settings. New York: Oxford University Press.

Mendes, E. G., Nunes, L. R. O. P., Ferreira, J. R., \& Silveira, L. C. (2004). Estado da arte das pesquisas sobre profissionalização do portador de deficiência. Temas em Psicologia da SBP, 12, 105-118.

Murta, S. G., \& Guimarães, S. S. (2007). Enfrentamento à lesão medular traumática. Estudos de Psicologia (Natal), 12, 57-63.

Pereira, C. S., \& Del Prette, A. (2008). Habilidades sociais em um grupo de funcionários com deficiência física: Há diferença entre sexo? In M. A. Almeida, E. G. Mendes, \& M. C. P. I. Hayashi (Eds.), Temas em educação especial: Múltiplos olhares (pp. 338-346). Araraquara, SP: Junqueira \& Marin.

Pereira, C. S., Del Prette, A., \& Del Prette, Z. A. P. (2009). Habilidades sociais de trabalhadores com e sem deficiência física. Psicologia: Teoria e Pesquisa, 25, 339-346.

Perry, E. L., Hendricks, W., \& Broadbent, E. (2000). An exploration of access and treatment discrimination and job satisfaction among college graduates with and without physical disabilities. Human Relations, 53, 923-955.

Sarriera, J. C., Câmara, S. G., \& Berlim, C. S. (2000). Elaboração, desenvolvimento e avaliação de um Programa de Inserção Ocupacional para jovens desempregados. Psicologia: Reflexão e Crítica, 13, 189-198.

Tanaka, E. D. O., \& Manzini, E. J. (2005). O que os empregadores pensam sobre o trabalho da pessoa com deficiência? Revista Brasileira de Educação Especial, 11, 273-294.

Thomas, A. P., Bax, M. C., \& Smyth, D. P. (1988). The social skill difficulties of young adults with physical disabilities. Child Care Health Development, 14, 255-264.

Wilson, S., Washington, L. A., Engel, J. M., Ciol, M. A., \& Jensen, M. P. (2006). Perceived social support, psychological adjustament, and functional ability in youths with physical disabilities. Rehabilitation Psychology, 51, 322-330. 